Article

\title{
Investigating Student Use of Technology for Engaged Citizenship in A Global Age
}

\author{
Brad M. Maguth * \\ Department of Curricular \& Instructional Studies, The University of Akron, Akron, OH 44325, USA; \\ E-Mail: bmaguth@uakron.edu; Tel.: +1-330-972-6319; Fax: +1-330-972-5209
}

Received: 1 February 2012; in revised form: 28 March 2012 / Accepted: 29 March 2012 /

Published: 18 May 2012

\begin{abstract}
This study undertook a five month qualitative investigation into technology use amongst twelve high school social studies students in two different sites in the Midwestern United States. This study examined students' use of technology and its relationship to three dimensions of citizenship in a global age: understand global events, issues, and perspectives, participate in global networks to communicate and collaborate with global audiences, and advocate on global problems and issues to think and act globally. Collecting data through semi-structured student interviews, online-threaded discussions and document analysis, I triangulated findings, and employed a qualitative approach. The study finds a relationship between student participants' use of technology and their serving as engaged citizenship in a global age. In using technology, students accessed international news and information, joined global networks to communicate and collaborate with global audiences, and produced digital content for international audiences.
\end{abstract}

Keywords: technology; global education; citizenship education; qualitative

\section{Introduction}

Seconds after President-Elect Barrack Obama surpassed the 270 electoral votes needed on 4 November 2008, the world learned of The United States' nomination of its first African American President through television, cell phones, text messaging, chat rooms, and online newspapers. At this moment in history, the world was tuned in and more connected than ever. More impressive than how new technologies were used by people to cover the presidential race was how Obama's campaign used 
these technologies to engage voters. Unlike any other presidential candidate in history, the U.S. President effectively used digital technologies to mobilize and organize supporters [1]. As potential voters learned of Obama's stance on issues and campaign tour stops at BarrackObama.com, many of these faithful supporters would learn of Obama's vice presidential running mate, Joe Biden, through a sent text message. Through the use of social networking websites like Facebook and Twitter, Obama was able to sign up over 2.4 million supporters. Team Obama seized the power of the Internet to gain the attention and support of young voters setting a strong precedent for future campaigns and elections [2].

New technologies are reshaping the skills, understandings and dispositions students need in a technologically advanced and globally interconnected age [3-5]. The world is flattening, and nation-states are more economically, politically, and socially interconnected than at any other previous time. For instance, as China's rising demand for automobiles and energy brings it into competition with other nations for resources, stock brokers in exchanges in London and New York cautiously monitor global oil supplies and its influence on global prices. Any fluctuations in supplies and prices are immediately communicated through such advanced technologies as smart phones, cable and network news, online newspapers, blogs, podcasts, and social networks. In the midst of this high tech environment, one must ask "what has the response been of schools, teachers, and more importantly students"?

\section{Literature Review}

Today, globalization and its influence can be easily observed in our daily lives in places like the gas pump, supermarket, and satellite TV broadcasts. Responding to an increase in global activity, the idea and practice of global education has been receiving a great deal of attention [6,7]. Global education is a response to a variety of economic, political, cultural, environmental, and technological forces that increasingly connect geographically distant and culturally diverse people [8,9]. Many global scholars claim an inadequacy in current education practice to teach students about the world's people, places, events, and the ways in which individuals and states are connected to a sophisticated global system [9-11]. In an increasingly global society, schools are beginning to take an active role in developing students that are effective players in an increasing pluralistic, interdependent, and changing world $[12,13]$.

Based upon a review of the literature, it is clear that social studies teachers can have a considerable influence in readying their students for active citizenship in a global and multicultural age $[13,14]$. To create a working theoretical framework of citizenship for a global age for use in this study, I examined scholarship in the area of global citizenship [14-16]. This theoretical framework provides three research-based dimensions of global citizenship that help frame this study. These dimensions include citizens in a global age being able to:

1. Understand global events, issues, and perspectives [13],

2. Participate in global networks to communicate and collaborate with global audiences [14],

3. Advocate on global problems and issues to think and act globally [17]. 


\section{A Battle Brews: Technology and Civic Engagement}

Over $90 \%$ of today's generation of U.S. students, or Millennials (those people roughly born between 1978 and 1996) are online, and over half of these users get political information from the Internet [18]. Students are not only using these technologies to access local and global social, political and economic information, but they are using these devices to communicate, collaborate, and advocate [19]. From rating their experience with sellers on ebay.com to mounting political opposition to corporate greed, today's youth are using electronic technologies to make a difference. The growing use of new technologies and their implications on the learning process has led many educational organizations and institutions to advocate technological literacy as a necessary skill for the $21 \mathrm{st}$ Century [20-24].

In many ways, these calls have often gone unanswered due to many schools suffering from a disproportionate lack of equipment, professional development, and technological infrastructure [25-27]. However, the U.S. digital divide is narrowing, and research shows that almost all students have gained access to both computers and the Internet in schools [23]. Even with this greater distribution and access, many studies conclude that the use of technology continues to be a "sleeping giant" with great unrealized potential on both teaching and learning [28-31].

The use of technologies offers students unprecedented opportunities to engage in public life $[32,33]$. Using the Internet, students can locate multiple information sources, communicate and collaborate with other members of a community, and even advocate/organize for a cause. While these traits are usually associated with civic engagement, using technology as a means to achieve civic literacy (local, national, regional, or global) has been controversial. According to Bennett [32], a battle brews between those in competing camps that see technology as a means of fostering civically engaged youth, versus those that view technology as disengaging youth. The disengaged view associates the growing use of new technologies by students as working against greater civic involvement. The supporters of this view believe the proliferate use of video games and the Internet only encourages individualism and social detraction [34]. Viewing technology as working contrary to the goals of civic engagement, followers cite decreasing patterns of social trust, participation in civil society, news consumption, and knowledge about government. For instance, David Buckingham [35] describes how the growing use of the Internet encourages participation and communications but calls into question its relation to civic engagement. Buckingham [35] advocated the need to differentiate between "media engagement" and "civic engagement". Followers of this theory believe that while the Internet and new technologies may well support participation and communication they can also serve to undermine the "civic" [27,34,36].

Another view, the engaged view, entrusts that students are using technology for personal expression, activism, and to project identities into a collective space [32,37]. Instead of passive consumers of information, new technologies hold the potential for students to become both producers and consumers. For instance, unlike any time before, students are using digital tools like Twitter, YouTube and Facebook to draw attention to important social, political, and economic issues. Peter Levin [37] has spoken out against an overtly negative view that labels today's generation of digital natives as civically lethargic and uninvolved. Describing how the "disengaged" viewpoint often portrays a simplistic narrative that overlooks large creative developments by youth in cyberspace, 
Levine [37] attributes value to the use of technology for informed and active democratic citizenship. Citing massive increases in youth volunteerism and study abroad, Levine [37] sees the Internet as holding the potential for youth to shape their political, economic and social environments. According to Lenhardt et al. [38] of the Pew Internet and American Life Project, the number of U.S. teenagers using the Internet has grown $24 \%$ in the past four years, and $87 \%$ of those between the ages of 12 and 17 are online. While the number of students using technologies has grown, their use inside the classroom suffers from many challenges [28-30]. Despite the absence and challenges of using these technologies in the classroom, many students are employing them outside of school in meaningful and civically relevant ways [32,37].

New technologies such as the Internet and online gaming offer a means for heightened civic participation [38-41], access to worldly information [42,43], and even social action [44,45]. For instance, Earl \& Shussman [45] describe how gamers used protests and demonstrations in both World of War Craft and Second Life to draw attention to unfair community policies and issues. Besides activism in video games, websites such as TakingITGlobal, Freerice.com, and iEARN, provide students with the means to make a difference politically, socially and economically in their world. Providing students with access to information, a means to collaborate and organize, and an ability to petition and protest, new technologies hold the potential to benefit citizenship education. As today's generation of citizens emerge, more research is needed that studies the ways in which students actually use the tools they are familiar with (technology) for citizenship in a global age.

\section{Technology and the Social Studies: A Story of Missed Opportunity}

Social studies education is one of the most important vehicles in the United States for civic education [6]. Most states in the U.S. offer and/or require PK-12 courses in subjects like American History, World History, Government, Economics, Political Science, Sociology, Psychology, as well as many other areas in the humanities and social sciences. As the largest professional association for social studies educators in the world, The National Council for the Social Studies (NCSS) defines the social studies as: the integrated study of the social sciences and humanities to promote civic competence... The primary purpose of social studies is to help young people make informed and reasoned decisions for the public good as a citizen of a culturally diverse, democratic society in an interdependent world [6].

Overall, civic competence and engagement is central to the mission of the social studies. However, the field of social studies faces many challenges in preparing citizens equipped to confront the challenges of the 21st Century. As evident in the massive International Association for the Evaluation of Education Achievement (IEA) survey of 90,000 fourteen-year old students in twenty-eight nations, civic education remains a largely teacher and textbook centered experience, disattached from the controversial and relevant issues students face [46]. With the U.S. government implementing No Child Left Behind (2002) ${ }^{1}$ (There is no footnote in our journal, please add it into the references) states continue to lean on high stakes testing to hold students, teachers, and schools accountable. In the name

\footnotetext{
${ }^{1}$ The No Child Left Behind Act of 2001 is a United States Act of Congress that supports standards-based education reform based on the premise that setting high standards and establishing measurable goals can improve individual outcomes in education. For more information see http://www2.ed.gov/nclb/landing.jhtml.
} 
of short-term gains on standardized test, social studies teachers have depended heavily on the use of textbooks that research indicates often devolves instruction into narrow perspectives and uninspiring activities [47,48]. Studies further indicate the damage this legislation has done in failing to provide students with a meaningful and engaging social studies experience [49-51].

As schools are facing increased challenges in educating informed and active citizens, schools are also gaining greater access to new technologies. From 3\% in 1994 of public schools in the United States having Internet access to over $98 \%$ in 2007 , the proliferation of quality access to the Internet is beginning to take off [52]. Due to the growing influence of new technologies on students, researchers have started to examine the potential of the use of new technology for civic and citizenship education [4,53-55]. While research in this area has grown, a technologically advanced era demands continuous assessment in how well schools and their proxy of civic education, the social studies, are fostering informed and active democratic citizens [6]. There is a need for research in civic education that addresses how technologies are being used by students [29,31,56-59], and how the personal use of technologies by students relate to the civic mission of schools and the social studies [32].

\section{Statement of the Problem}

In my study, I investigated how the use of technology by students related to three different dimensions of engaged citizenship in a global age. Although the personal use of technology amongst teachers and students is growing [60], it seems as if the application of new technologies has yet to fully transcend into the classroom. As a result, many researchers describe a "very thin knowledge base" on research on the use of interactive technologies in schools; especially the social studies [23,31]. There have been two studies in particular that have examined the use of technology on students' sense of civic duty and rights. In Heafner's study, students were assigned the task of researching and creating a campaign advertisement for a local senatorial candidate [61]. As one of the few studies that examined the use of technology by students in the social studies, this research concluded that the use of the Internet and PowerPoint influences students' civic enthusiasm, motivation and engagement. However, Heafner failed to consider other variables besides the use of technology, such as the studentcenteredness of the activity, which could have influenced student engagement and motivation. Another study by Cynthia Sunal aimed to investigate how students' use of technology influenced their engaging in civic events, and its implications on civic education [62]. Ironically, this study was dependent upon the analysis of student work and teacher focus groups to try and interpret student conceptions of citizenship. Sunal did not conduct any student interviews, or, even directly question students on their experiences with technology or citizenship. Like most studies conducted on students' views towards citizenship, outsiders were given authority to provide their expertise to try and interpret student views.

Overall, neither of these studies looked more broadly at how students' use of technology related to engaged citizenship in a global age. As schools move to prepare citizens to live in an increasingly interconnected world, more research is needed that investigates the instructional strategies and tools that are best suited for this mission [63]. Given a large deficit in high quality studies that examines how the use of technology by students relates to civic learning in a global age, more research in this area is greatly needed $[3,29,64]$. 


\section{Research Question}

In my study, I investigated how the use of technology by students related to three different dimensions of engaged citizenship in a global age. This included analyzing how students use technology to access and think through information, make decisions, communicate and collaborate. This research also investigated the ontological beliefs of students surrounding citizenship, and the ways in which they employed different technologies to forge the skills, understandings, and attitudes needed for engaged citizenship in a global age. This study answers the following research question: In what ways does students' use of technology relate to engaged citizenship in a global age?

\section{Methodology and Research Design}

\subsection{A Qualitative Inquiry}

In researching possible approaches to this study, I located an approach that prioritized student perspectives on both their use of technology, and their views towards citizenship. In prior studies on citizenship education, researchers have often employed interviews and focus groups that have surprisingly prioritized the perspectives of teachers to better understanding student perspectives on citizenship in a global age $[62,65]$. Furthermore, in a review of previous research, I could not locate any studies that allowed students the opportunity to provide their perspectives of the ways in which their use of technology relates to citizenship education. Unlike many previous studies, students in this particular study were given an opportunity to describe what knowledge, skills, and attitudes were necessary for engaged citizenship in a global age. Angela Cook-Sather describes how, "We as educators and educational researchers must seriously question the assumption that we know more than the young people of today about how they learn or what they need to learn... it's time we count students among those with authority [66]". The selected research approach provided students, all of whom are natives to a global and technologically sophisticated age, with the opportunity to be counted amongst those with authority in what constitutes engaged citizenship in a global age.

Another important consideration in selecting a research approach included it allowing me the freedom to have student participants use technology in describing their uses of technology, and their views on engaged citizenship. The selected approach provided student participants with the opportunity to richly discuss important events and experiences that have shaped their perceptions of citizenship. This chosen approach allowed for the collection of data through technologically enhanced methods, namely online threaded discussions. By offering student participants a means to contribute their perspectives and experiences on their use of technology and its relation to civic education, I was able to gain "rich" and "thick" data. While researchers are beginning to use electronic technologies to collect data [67], further research indicates the need for researchers to employ 21 st Century tools in the data collection process [68].

With these two considerations in mind, a qualitative approach was selected as a best fit for this study. Instead of using a quantitative approach that seeks to confirm a hypothesis [69], this study aimed to utilize more inductive means to generate new knowledge. According to Corbin and Strauss, areas where little is known can often benefit from a qualitative approach [70-71]. This is especially of importance since research in the area of technology and the social studies [29,31], and in technology 
and democratic citizenship, is in its infancy [32,61,64,71]. The use of a qualitative approach was essential in laying the initial foundation of knowledge and factors in this context.

\subsection{Participants \& Data Collection}

I used purposeful sampling to select two teachers (each at different schools) and twelve students (six from each school) that actively and meaningfully used technology. While this process of selection does have its drawbacks, Patton concludes this form is ideal for researchers striving to locate information rich cases [72]. To locate possible student participants, high school social studies teachers were initially screened based upon their having at least two years of teaching experience, and in opportunities afforded to students in class to use technology meaningfully.

After locating and gaining the informed consent of two teacher participants, I progressed towards the selection of student participants. Potential student participants were recommended for the study by their teachers based upon provided criteria. While teachers provided recommendations, the final decision for the selection of students was made by me. Possible student participants were screened through interviews by me based upon these criteria.

Criteria for the selection of final student participants include:

1. Invited students from diverse environments and backgrounds to participate. All students had to have been enrolled in a selected social studies teacher's high school classroom;

2. Participated in a preliminary interview whereby students were asked to demonstrate their level of expertise and usage of technology at home and in the social studies classroom. Students were asked to illustrate ways in which they use technology to access information, communicate, and create digital artifacts;

3. Gained the informed consent of their legal guardian(s), and offer their informed assent to participate in the study. Furthermore, they were willing to provide the time and effort required for participation in the study.

For a period of eleven weeks, I collected data from two schools (an urban school and a suburban school) in the Midwestern United States. Data were collected through semi-structured interviews with twelve students (4 rounds). All participants were assigned pseudonyms for this study, and collected data was held in the strictest confidentiality. The twelve student participants were asked to contribute to an online threaded discussion once a week (for student participant demographic information see table below). This invite-only online threaded discussion asked students to identify specific technologies they have used, and what they gained from its use. Furthermore, this forum served as an online community whereby students discussed different technologies that hold potential for engaged citizenship in a global age. My reflective notes served as another means of data. Themes for the audio recorded and transcribed semi-structured participant interviews included: (1) Background information about the participants and their context; (2) Ways students access/use, and their experiences with, electronic technologies; (3) Participants' understanding of citizenship in a global age; (4) Description of what is gained and lost when students and teachers use technology for civic education. 
Table 1. Student participants at alpha and beta high schools.

\begin{tabular}{|c|c|c|c|c|c|c|c|c|c|}
\hline \multicolumn{5}{|c|}{ Alpha High School students' demographics } & \multicolumn{5}{|c|}{ Beta Early College High School students' demographics } \\
\hline Name & Age & Ethnicity/Race & Sex & Grade & Name & Age & Ethnicity/Race & Sex & Grade \\
\hline $\begin{array}{c}\text { Sarah } \\
\text { McIntyre }\end{array}$ & 18 & Caucasian & $\mathrm{F}$ & 12 th & $\begin{array}{c}\text { Jeff } \\
\text { Cantor }\end{array}$ & 16 & Caucasian & M & 10 th \\
\hline $\begin{array}{l}\text { Justin } \\
\text { Steiner }\end{array}$ & 14 & $\begin{array}{c}\text { Arab } \\
\text { American }\end{array}$ & M & 9 th & $\begin{array}{c}\text { Eman } \\
\text { Hassan }\end{array}$ & 15 & $\begin{array}{l}\text { Palestinian- } \\
\text { American }\end{array}$ & $\mathrm{F}$ & 10th \\
\hline $\begin{array}{l}\text { Sharron } \\
\text { McPeek }\end{array}$ & 17 & Caucasian & $\mathrm{F}$ & 12 th & $\begin{array}{c}\text { Brad } \\
\text { Masters }\end{array}$ & 16 & Caucasian & M & 10 th \\
\hline $\begin{array}{l}\text { Cindy } \\
\text { Lane }\end{array}$ & 15 & Caucasian & $\mathrm{F}$ & 9th & $\begin{array}{c}\text { Lisa } \\
\text { Williams }\end{array}$ & 15 & Caucasian & $\mathrm{F}$ & 10th \\
\hline James Ryan & 18 & Caucasian & M & 12 th & $\begin{array}{l}\text { Denish } \\
\text { Kumar }\end{array}$ & 15 & $\begin{array}{c}\text { Indian } \\
\text { American }\end{array}$ & M & 10th \\
\hline $\begin{array}{c}\text { Patrick } \\
\text { Fitzgerald }\end{array}$ & 18 & Caucasian & M & 12 th & $\begin{array}{c}\text { D'Angelo } \\
\text { Hall }\end{array}$ & 15 & $\begin{array}{c}\text { African } \\
\text { American }\end{array}$ & M & 10 th \\
\hline
\end{tabular}

\subsection{Data Analysis}

Over 694 pages of data were collected throughout a three month span. Since qualitative data rapidly accumulates in the collection process, timely and consistent analysis helped sort out significant features for data reduction [73]. This sorting process involved a "progressive focus" whereby the researcher works to gather, sift through, review and reflect on data [74]. This process involved examining the data and organizing elements into general categories/open codes. The intention involved moving from a description to explanation and theory generation [75]. As this process unfolded, the following categories emerged from the data: International News and Information, Global Networks, and Production of Digital Content for Global Syndication.

\subsection{Limitations of the Study}

As an outsider, there are always concerns with the researcher's representations of the study. Since I understand the degree to which the researcher is the primary instrument of data collection and analysis [76], I recognize that my interpretations of the findings and understandings are limited based upon my cultural experience. As an avid consumer and student of electronic technologies, I find myself privileged in having access to them; which is far from the universal global experience. In looking at the ways in which students' use of technology relates to engaged citizenship in a global age, I also find my cultural experience with citizenship as having been one of privilege; quite contrary to the experiences of many marginalized and discriminated against groups. So in many ways this study stems from my own cultural assumptions and experiences with technology and citizenship. My pre-constructed knowledge influenced the study during the data collection, analysis, and reporting. This pre-constructed knowledge mandated my undergoing a 'reflexive account' to clarify my positionality and experiences to my audience [77]. Besides the weaknesses that accompany any qualitative approach [78], the number of participants in no way encapsulates a representative sample for generalizable results. 


\section{Results}

\subsection{International News and Information Consumers}

Students are using technology to access information, to communicate, and to solve problems. Instead of using more stagnant traditional print based sources like encyclopedias, phone books, and newspapers, students are using online search engines, like Google, to locate massive amounts of information. Lisa, Denish, Jeff, Brad, James, Pat, and Sarah extensively commented on their use of Google's search engine. For instance, during the 2008 Presidential Election, Lisa, Jeff, Sharron, and D'Angelo all noted how they did extensive research only using the Internet to learn about the different U.S. presidential candidates. In describing his use of search engines, Jeff stated, "Our world is changing. There's so much information at your fingertips, and it's so much easier to find out about things. You can find them out so fast (Student Interview 2, 8 April 2009)".

The Internet provides students with access to large amounts of information. Like never before, students can use the Internet to monitor global and national issues in real time. For instance, Pat expressed how "The news is always changing, and if you don't have the ability to access information than you would have tunnel vision. If you have technology you can have access to new stuff and perspectives. You can access other sources and have a wider view (Student Interview 3, 1 May 2009)".

This was a common theme amongst students in that they are afforded the opportunity to access multiple sources of information through the Internet. Sharron comments that "We can now access information on our cell phones, on the Internet, and on our iPads.... We can also use go to multiple websites to fact-check and learn the other side of the story (Student Interview 2, 2 April 2009)".

These students are also using technology to stay up-to-date on current events. This use of technology to stay abreast on important issues includes Sarah's daily readings of the Online New York Times (Student Interview 1, 13 March 2009), Brad's consistent listening to BBC streaming video (Student Interview 2, 8 April 2009), and Justin's use of Google Earth to learn about geopolitical quarrels between India and Pakistan (Student Interview 2, 1 April 2009). One student in particular was quite passionate about the possibilities of using technology to access multiple perspectives on global issues. During our second round of Interviews, Eman commented, “Too often we don't know what's going on beyond our border. Last month, people in Gaza were under siege and over 1000 people were injured and over 200 died... I like to view things from many angles. I visit many different sources... like the Palestinian web, the BBC, and CNN International (Student Interview 2, 13, April 2009)". As technology advances, students described their comfort level in using digital tools to learn about important, social, political, and economic issues.

This finding addresses Merryfield and Wilson's [13] dimension of global citizenship which includes citizens being able to understand global events, issues, and perspectives. Students used technology as their primary means to learn about issues and events outside of their country's borders. Furthermore, students turned to online global news outlets like the BBC and CNN International to access multiple perspectives and voices. 


\subsection{Global Networks}

Students are also using technology to create social, political, and economic networks. Most of the students acknowledged using the Internet to review prices and to make online purchases. With large amounts of information on the prices of goods and the quality of the service offered by suppliers, students seem to be using the Internet to make informed consumer decisions. During our first interview, Pat described how he frequently goes online to compare prices and to make purchases. After researching the different reviews of low price sellers on Amazon.com left by other consumers, Pat made an informed decision when purchasing a video game (Student Interview 1, 13 March 2009). Pat noted during our first interview that, "If I read a bad review, I won't do business with that seller." After the game was shipped to his house, Pat commented on how he went back to Amazon.com to describe the quality of service he received so that consumers around the world could make informed decisions on both the quality of the product and quality of service offered by the vendor (Student Interview 1, 13 March 2009). This is just one example of how students are using technology to communicate and to build connections with people.

With the advent of social networking, students are frequently using websites like Facebook and Twitter to establish connections. Participants acknowledge extensive use of social networking sites to maintain social connections to friends and classmates. With a very busy schedule of school and numerous extracurricular commitments, James uses Facebook (and its related Facebook Messenger) to “...have many quick conversations without having to make timely, expensive phone calls. Since my schedule is hectic, Facebook really helps me out (Student Interview 1, 10 March 2009)".

Outside of sustaining friendships, a few students used the social utility to extend social connections. James, Pat, Sharron, and Denish all described their befriending politicians and groups on social networking sites. James commented, 'I'm actually friends with many nongovernment organizations like the United Nations on my Facebook page... I get regular status updates on global events and humanitarian issues on my [Facebook] wall (Student Interview 2, 17 April 2009)".

The proliferation of new technologies is allowing for new opportunities in civic engagement in a global age. In accessing electronic technologies, students are provided both synchronous and asynchronous means of communication and collaboration. The Internet in particular affords student participants immediate opportunities to listen to, speak to, and work with geographically distant and culturally diverse populations. In our first interview, Sarah commented on how the Internet provides users with the opportunity to "...see what's going on around you, and you can read about other people's lives on blogs." She goes on to comment how the Internet "...makes the world a smaller place. You can talk to somebody in Australia so fast (Student Interview 1, 13 March 2009)". Having friends around the world, Sarah uses both Facebook and Skype to communicate with friends situated around the world. Spelling out how globalization has brought citizens of the world together, Sarah comments, "I think it (the Internet) is cool. It brings a lot of people together from everywhere. Somebody all the way in Japan can be viewing the same webpage you're viewing (Student Interview 1, 13 March 2009)".

As technology spreads globally, students are finding themselves interacting with global populations. D'Angelo and Justin are both self described 'gamers' that frequently play massively multiplayer online role playing games (MMORPG) with people all around the country and world. 
When asked about what he likes about 'gaming', D'Angelo commented, “There are people all over the world playing these games. They have different backgrounds, different perspectives on how they see stuff. I guess I get to learn different stuff from different people (Student Interview 1, 12 March 2009)".

When discussing his online quests, D'Angelo described how he often strategizes and works with his online friends in Poland, Russia, and Greenland to solve quests. This global collaboration amongst various 'users' has allowed D'Angelo to be quite successful at 'gaming.' Justin also expressed how he enjoys playing games with people on the opposite side of the world. To him, this use of technology demonstrates, "The distance between countries is getting smaller. It really shows me how small our world really is, and that the world we're in today is very much globalized. You can talk to someone on the opposite side of the global immediately (Student Interview 1, 10 March 2009)".

Many of the students acknowledged an increasing dependency on text messaging. For instance, in the month of March, Eman used over 1400 text messages and James used over 1200 text message. Both James and Eman acknowledged receiving text messages from advocacy groups. During the 2008 Presidential contest, they received frequent text messages from Barack Obama's campaign, which included updates on campaign tour stops and Obama's Vice-Presidential selection of Joe Biden. In receiving text messages from the Obama Campaign, students have been able to learn about Obama plans for healthcare reform, energy, and the environment.

New technologies are affording students the opportunity to communicate and collaborate with one another. In an online posting to a threaded discussion, Patrick expressed how he had been using Geocaching, an outdoor treasure hunting game whereby participants use global positioning systems (GPS) to locate containers (or "caches"), to communicate and collaborate with other people. He described that when participants locate these containers, they enter information into a logbook, and relocate it. Visitors are able to use the website to track the position of different 'caches' that users hide. This sport provides users the opportunity to use technology to locate and communicate the whereabouts of different 'caches.' Patrick, in an online posting, described how this digitally based sport, "Allows people from all over the country and world to share experiences... I have met many interesting people and visited many interesting places... this sport allows people to enjoy the beauties of nature that's all around them (Threaded Discussion, 6 April 2009)”. Geocaching and many other new technologies are bringing citizens together to explore and learn about geography.

This finding addresses Gaudelli's [14] dimension of global citizenship which includes citizens being capable and willing to participate in networks to communicate and collaborate with global audiences. Students used technology to join organizational networks, and to communicate and collaborate with geographically distant and culturally diverse populations. Participation in these networks allowed students to learn about and with global audiences.

\subsection{Digital Producers}

Besides using technology to access information and communicate, students are also turning to the Internet to digitally produce new media. The Internet has opened up a whole new audience for students and citizens to share their work. Instead of passively sitting back and reading and watching the views and perspectives of others, today's students are able to use technology to create digital artifacts that contribute to the civic discussion. For instance, after viewing YouTube videos on the Iraq war, Pat 
become irritated with what he perceived to be a liberal bias to traditional news coverage. During our first interview, Pat explains, "I made this video about the Iraq War because I'm very much for the war effort. Since there are a lot of opinions on the Internet about the War, I wanted to create a video that gave proper information on it (Student Interview 1, 13, March 2009)". Detecting bias coverage of the War, Pat created and posted a video online to better inform others around the world of his perspective on the conflict. Even after uploading the video, Pat was sure to follow what people were saying about his video. He was quick to point out that it received over 50 comments. When asked about the advantages of posting a video to a site like YouTube, Pat stated, "It's like an informal discussion. You get other views, and you get to counteract those views. You get to have those sort of discussions with people of the same and opposite views. It's a way to learn about other people's views (Student Interview 1, 13 March 2009)".

Other students turned to YouTube to both upload videos, and to comment on other people's ideas. Many students commented on their reliance on YouTube to watch videos on the different political candidates during the 2008 campaign season. For social studies class, both Eman and Jeff have posted their original works to YouTube for public viewing. Eman's digital documentary encourages states to double their efforts through the United Nations to empower females (Document Analysis: Baraka Project, 5 March 2009). During an informal conversation, Eman commented on how she enjoyed having the opportunity to showcase her work to a wider audience outside of just her class (Reflective Journal, 10 March 2009). As a frequent up-loader of videos to YouTube, Jeff commented on how people are more likely to watch a video over just reading a brochure. During our second interview Jeff states, "The video is just more interesting. You can have sound, images, and video. It's more of an experience (Student Interview 1, 12 March 2009)". Jeff's latest YouTube video encouraged online viewers to take action in helping nation-states in sub-Saharan Africa have access to clean water supplies.

One of the most prolific student users of YouTube was Denish. He is a frequent consumer and producer of digital movies on the website. Having posted over 30 videos to YouTube, Denish discussed how he got started posting movies to the Internet, "I used to see these videos on YouTube. Eventually, I began to watch YouTube movies on how to make YouTube movies. I also asked people questions... these YouTube users. And they really taught me how to do it. And then I became interested in it (Student Interview 1, 12 March 2009)".

Denish has posted a variety of different digital shorts to YouTube that have been accessed from around the world. Some of his most serious work on YouTube provides visitors with short tutorials on such computer software programs as Adobe's Photoshop and After Effects. He has also made available to the public a short digital documentary he created in social studies class concerning the horror of WWII (Document Analysis: WWII YouTube Video, 9 March 2009). When asked what he likes best about the Internet, Denish commented, "People post, and you learn. Then, you post what you learn, and people can learn from you. You get to share your knowledge with people from all over the world (Student Interview 1, 12 March 2009)".

New technologies provided student participants with the opportunity to access international news and information, to join global networks, to communicate and collaborate with global audiences, and to produce digital content for global syndication. These technologies, all located in the students' digital backyard, afford them the opportunity to watch, read, listen to, and create news. As a result, they are 
able to listen to, speak to, and work with geographically distant and culturally diverse populations.

This finding addresses Diaz's et al. [17] dimension of global citizenship which includes citizens moving beyond knowing about local and global issues to actually being capable and willing to take action in order to create a more prosperous, peaceful, and just planet. These participants used the technologies they were familiar with to advocate on global problems and issues. In the process, students used technology to express their opinions, to showcase their research, and to engage in global conversations on important issues and events.

\section{Discussion}

I framed this study drawing from three research-based dimensions of citizenship in a global age $[13,14,17]$. This study finds that a relationship exists between these three dimensions and students' use of technology to learn about the world and its people. In using technology, students accessed international news and information, joined global networks to communicate and collaborate with global audiences, and produced digital content for global audiences. Of these different dimensions, the data most clearly supports students' use of technology to join global networks in order to communicate and collaborate with audiences [14]. Based on the data I obtained, the students collectively used technology to learn about the world, its people, and issues.

However, I am less satisfied with how this study explains participants' use of technology for digital production [17]. I hoped this study would showcase innovate ways youth were using technology to produce and advocate for global causes. Unfortunately, I found little evidence that students were self-directed in using technology to take action on global issues and challenges. Most of the examples provided stemmed from classroom assignments and discussions in the social studies. On the one hand, I recognize the limited nature of this study (i.e., limited timeframe and participants). Future research in this area must take this into account by establishing studies that better document the ways in which students use technology for digital production outside of the social studies classroom for citizenship in a global age.

The fact remains that an increasing number of youth are gaining access to, and frequently using, technology. More than two-thirds of the people in the United States have Internet connections at home, with the majority having broadband connections [79]. By 2014, it is estimated that $90 \%$ of all people in the United States will have high speed Internet connections [80]. With over $90 \%$ of school age youth using the Internet, and ages 12-17 representing the largest and fastest growing segment of users $[81,82]$, educators in general are going to have to rethink how they go about teaching an increasingly digital student body. In this regard, my study supports an emerging body of literature on technology in social studies education $[4,31,39,83,84]$.

As the renowned educational philosopher John Dewey suggests, we must continually ask ourselves "to what degree does the enacted curriculum align to the needs and interests of students and society [85]?" As students increasingly access information, communicate, shop, organize, network, collaborate, and advocate using electronic technologies, teachers must reflect on the instructional methods they use to engage digital learners. Sarah, Justin, Sharron, and Cindy all acknowledged the dullness of having to consistently take notes while in social studies class. These same participants noted their interest towards digitally mediated activities that promote collaboration, creativity, and an 
awareness of global issues. Social studies teachers must be at the forefront of seizing the educative potential of technology, as it is the field most predicated on equipping students with the understandings, skills, and attitudes for engaged citizenship in a global age [6].

Technology allows new possibilities for engaged citizenship in global age and in the social studies classroom. Today's technologies provide students with the opportunity to immediately access primary source information, songs, and movies, and to use these materials to produce new digital products. Students can now access real time news and communicate with segments of the global population. While technology allows for new possibilities in the social studies, prompting many to claim it could benefit the most from the use of these technologies [29,39], the social studies field in general has been the most reluctant in seizing the educative potential of technology [28,30,31]. All of the student participants frequently used social networking sites, and many of them connected with their elected leaders, advocacy groups, and colleges to voice their opinions. This relates to national trends that cite over $55 \%$ of teenagers being involved in online communities, mainly through social networking websites, outside of school whereby they exchange and request information, share photos, develop and maintain social and professional networks, and remix digital content [38]. A great deal of research indicates that the social studies in particular fails to keep the interest of a majority of students $[36,39,74]$. Through the abuse of lecture, textbooks, and other forms of didactic instruction, the social studies has often strayed from its mission of teaching social education [86-89]. With new technologies allowing for new forms of student participation, communication and interest, the social studies in particular must reaffirm its allegiance to using relevant tools that students are excited about and interested in to build connections between culturally diverse and geographically distant populations $[32,41]$. In a technologically sophisticated age, this sort of curricular congruence is vital in preparing engaged citizenship for a global age.

\section{Conclusions}

This study undertook a five month qualitative investigation into technology use amongst twelve high school social studies students in two different sites in the Midwestern United States. It examined students' use of technology and its relationship to three dimensions of citizenship in a global age: Understanding global events, issues, and perspectives [13], participating in global networks to communicate and collaborate with global audiences [14], and advocating on global problems and issues to think and act globally [17]. Data was collected through semi-structured student interviews, online-threaded discussions, and document analysis to triangulate findings. The study finds a relationship between student participants' use of technology and their serving as engaged citizenship in a global age. In using technology, students accessed international news and information, joined global networks to communicate and collaborate with global audiences, and produced digital content for international audiences.

\section{Acknowledgements}

I would like to thank Bryan Burns, Jeremy Hilburn, and my partner Joey McPeek for all their help in reviewing and formatting this manuscript. 


\section{References and Notes}

1. Sanchez, L. Commentary: GOP needs to catch up to Obama's Web Savvy. CNN Politics, 8 November 2008. Available online: http://articles.cnn.com/2008-11-07/politics/sanchez. technology_1_obama-s-web-facebook-barack-obama?_s=PM:POLITICS (accessed on 16 April 2012).

2. Technology and the campaigns: Flickring here, twittering there. Economist, 14 August 2008. Available online: http://www.highbeam.com/doc/1G1-183363993.html (accessed on 16 April 2012).

3. Merryfield, M. Using electronic technologies to promote equity and cultural diversity in social studies and global education. Theor. Res. Social Educ. 2000, 28, 502-226.

4. Friedman, A.M.; Hicks, D. The state of the field: Technology, social studies, and teacher education. Contemp. Issues Technol. Teach. Educ. 2006, 6, 246-258.

5. Maguth, B. Connecting students globally: The effects of infusing technology into the global classroom. In Proceedings of Society for Information Technology and Teacher Education International Conference, Las Vegas, NV, USA, 3 March 2008.

6. National Council for the Social Studies. Preparing citizens for a global community. Soc. Educ. 1 May 2004. Available online: http://www.socialstudies.org/positions/global (accessed on 16 April 2012).

7. Reimers, F. Global Competency Is Imperative for Global Success. The Chronicle of Higher Education, 30 January 2009. Available online: http://chronicle.com/article/Global-CompetencyIs/9742 (accessed on 16 April 2012)

8. Alger, C. Global connections: Where am I? How did I get here? Where am I going? Soc. Educ. 1998, 62, 272-275.

9. Case, R. Key elements of a global perspective. Soc. Educ.1993, 57, 318-325.

10. Anderson, L.F. An examination of the structure and objectives of international education. Soc. Educ. 1968, 35, 639-652.

11. Becker, J.M. Goals for global education. Theor. Res. Social Educ. 1982, 21, 228-233.

12. Kniep, W.M. Defining a global education by its contents. Soc. Educ. 1986, 50, 437-446.

13. Merryfield, M.; Wilson, A. Social Studies and the World: Teaching Global Perspectives; National Council for the Social Studies: East Lansing, MI, USA, 2005.

14. Gaudelli, W. World Class: Teaching and Learning in Global Times; Lawrence Erlbaum Associates: Mahwah, NJ, USA, 2003.

15. Myers, J.P. Rethinking the social studies curriculum in the context of globalization: Education for global citizenship in the U.S. Theor. Res. Social Educ. 2006, 34, 370-394.

16. Noddings, N. Educating Citizens for Global Awareness; Teachers College Press: New York, NY, USA, 2005.

17. Diaz, C.F.; Massialas, B.G.; Xanthopoulus, J.A. Global Perspectives for Educators; Ally Bacon: Boston, MA, USA, 1999.

18. Leyden, P.; Teixeira, R. The Progressive Politics of the Millennial Generation: The Emerging Evidence on Why the Younger Generation is Boosting Progressive Prospects for the Early 21st Century; The New Politics Institute: Washington, DC, USA, 2007. 
19. Rainie, L. Teens and Technology; Public Library Association: Washington, DC, US, March 2006.

20. National Council for Accreditation of Teacher Education. Professional Standards for the Accreditation of Teacher Preparation Institutions; National Council for Accreditation of Teacher Education: Washington, DC, USA, 2008.

21. NETS Project, Susan B.Y. National Education Technology Standards for Students; International Society for Technology in Teacher Education: Eugene, OR, USA, 2007.

22. Ohio Department of Education. Technology Academic Content Standards; Ohio Department of Education: Columbus, OH, USA, 2003.

23. United States Department Education Office of the Secretary. National Education Technology Plan, Toward A New Golden Age In American Education: How the Internet, the Law and Today's Students Are Revolutionizing Expectations; United States Department of Education: Washington, DC, USA, 2004.

24. Wells, J;; Westat, L.L. Internet Access in US Public Schools and Classrooms: 1994-2003; United States Department of Education: Washington, DC, USA, 2003

25. Cuban, M. Oversold and Underused: Computers in Classrooms; Harvard University Press: Cambridge, MA, USA, 2003.

26. U.S. Department of Commerce. A Nation Online: Entering the Broadband Age; National Telecommunication and Information Administration: Washington, DC, USA, 2004.

27. Banks, A. Race, Rhetoric, and Technology: Searching for Higher Ground; Lawrence Erlbaum Associates Inc.: Mahwah, NJ, USA, 2006.

28. Ehman, L.H.; Glenn, A.D. Interactive technology in the social studies. In Handbook of Research on Social Studies Teaching and Learning; Shaver, J.P., Ed.; MacMillan Reference Books: Hampshire, UK, 1991; pp. 513-522

29. Berson, M. Effectiveness of computer technology in the social studies: A review of the literature. J. Res. Comput. Educ. 1996, 28, 486-499.

30. Martorella, P.H. Technology and the social studies-or: Which way to the sleeping giant? Theory Res. Social Educ. 1997, 25, 511-514.

31. Whitworth, S.A.; Berson, M.J. Computer technology in the social studies: An examination of the effectiveness literature (1996-2001). Contemp. Issues Technol. Teach. Educ. 2003, 2, 472-509.

32. Bennett, W.L. Changing citizenship in the digital age. In Civic Life Online: Learning How Digital Media Can Engage Youth; The MIT Press: Cambridge, MA, USA, 2008; pp. 1-24.

33. Palfrey, J.; Urs, G. Born Digital: Understanding the First Generation of Digital Natives; Basic Books: New York, NY, USA, 2008.

34. Putnam, R. Bowling Alone: The Collapse and Revival of American Community; Simon \& Schuster Paperbacks: New York, NY, USA, 2000.

35. Buckingham, D. Introducing identity. In Youth, Identity, and Digital Media; The MIT Press: Cambridge, MA, USA, 2008; pp. 1-24

36. Barber, B.R. Strong Democracy: Participatory Politics for a New Age; The University of California Press: Los Angeles, CA, USA, 1984.

37. Levine, P. A public voice for youth: The audience problem in digital media and civic education. Bennett, W.L., Ed; In Civic Life Online: Learning How Digital Media Can Engage Youth; The MIT Press: Cambridge, MA, USA, 2008; pp. 119-138. 
38. Lenhart, A.; Madden, M.; Macgill, A.R.; Smith, A. Teens and Social Media; Pew Charitable Trusts: Washington, DC, USA, August 2008.

39. Van Fossen, P.; Berson, M. The Electronic Republic: The Impact of Technology on Education for Citizenship; Purdue University Press: West Lafayette, IN, USA, 2008.

40. Rheingold, H. Using participatory media and public voice to encourage civic engagement. Bennett, W.L., Ed; In Civic Life Online: Learning How Digital Media Can Engage Youth; The MIT Press: Cambridge, MA, USA, 2008; pp. 97-118.

41. Friedman, A. Exploring guild participation in MMORPGs and civic leadership. In Gaming for Classroom-based Learning; College and University Faculty Association (CUFA): Houston, TX, USA, 2008; Available online: http://www.igi-global.com/chapter/gaming-classroom-basedlearning/42694 (accessed on 2 December 2008)

42. Flanagin, A.J.; Metzger, M.J. The role of site features, user attributes, and information verification behaviors on the perceived credibility of web-based information. New Media Soc. 2007, 9, 319-342.

43. Gee, J.P. What Video Games Have to Teach Us about Learning and Literacy? Palgrave MacMillan: New York, NY, USA, 2003.

44. Kennedy, J.; Zanetis, J. Developing global citizens: The global run project. Learn. Lead. Technol. 2007, 35, 27-28.

45. Earl, J.; Schussman, A. Contesting cultural control: Youth culture and online petitioning. Bennett, W.L., Ed.; In Civic Life Online: Learning How Digital Media Can Engage Youth; The MIT Press: Cambridge, MA, USA, 2008; pp. 71-96.

46. Torney-Purta, J.; Amadeo, J.; Lehman, R. Civic Knowledge and Engagement at Age 14 in 28 Countries: Results From the IEA Civic Education Study; ERIC Clearinghouse for Social Studies/Social Science Education, Indiana University: Boulder, CO, USA, 2001.

47. Cuban, L. History of teaching in social studies. Shaver, J., Ed.; In Handbook of Research on Social Studies Teaching and Learning; New York: Macmillan: New York, NY, USA, 1991; pp. 197-209

48. Chiodo, J.; Beyford, J. Do they really dislike social studies? A study of middle school and high school students. J. Soc. Stud. Res. 2004, 28, 16-26.

49. Bailey, G.; Shaw, E.L; Hollifield, D. The devaluation of social studies in the elementary grades. J. Soc. Stud. Res.2006, 20, 18-29.

50. O’Connor, K.A.; Heafner, T.; Groce, E. Advocating for social studies: Documenting the decline and doing something about it. Soc. Educ. 2007, 71, 255-260.

51. Vogler, K.; Virtue, D. "Just the facts, ma'am": Teaching social studies in the era of standards and high-stakes testing. Soc. Stud. 2007, 98, 54-58.

52. Parsad, B.; Jones, J.; National Center for Education Statistics. Internet Access in U.S. Public Schools and Classrooms: 1994-2003; USA Department of Education, Institute of Education Sciences, National Center for Education Statistics: Washington, DC, USA, 2003.

53. Mason, C.; Berson, M.; Diem, R.; Hicks, D.; Lee, J.; Dralle, T. Guidelines for using technology to prepare social studies teachers. Contemp. Issues Technol. Teach. Educ. 2001, 1, Article 5967171. Available online: http://www.citejournal.org/vol1/iss1/currentissues/socialstudies/ article1.htm (accessed on 16 April 2012). 
54. Bolick, C.M. Digital archives: Democratizing the doing of history. Int. J. Soc. Educ. 2006, 21, $122-134$.

55. VanFossen, P.J.; Waterson, R. It is just easier to do what you did before? An update on Internet use in secondary social studies classrooms Indiana. Theor. Res. Soc. Educ. 2008, 36, 124-152.

56. Braun, J.A.; Risinger, C.F. Surfing Social Studies: The Internet Book; National Council for the Social Studies: Washington, DC, USA, 1999.

57. Diem, R.A. Can it make a difference? Technology and the social studies. Theor. Res. Soc. Educ. 2000, 28, 493-501.

58. Doolittle, P.; Hicks, D. Constructivism as a theoretical foundation for the use of technology in social studies. Theor. Res. Soc. Educ. 2003, 31, 72-104.

59. Berson, M.; Balyta, P. Technological thinking and practice in the social studies: Transcending the tumultuous adolescence of reform. J. Comput. Teach. Educ. 2004, 20, 141-150.

60. Rainie, L.; Jorrigan, J. A decade of adoption: How the Internet Has Woven itself into American Life; Pew Charitable Trusts: Washington, DC, USA, 2005.

61. Heafner, T. Using technology to motivate students to learn social studies. Contemp. Issues Technol. Teach. Educ. 2004, 4, 42-53. Available online: http://www.citejournal.org/vol4/iss1 /socialstudies/article1.cfm (accessed on 16 April 2012)

62. Sunal, C.S. What is a citizen? The impact of the Internet on definitions of citizenship. In the Electronic Republic? The Impact of Technology on Education for Citizenship; Purdue University Press: West Lafayette, IN, USA, 2008; pp. 37-55.

63. Van fossen, P. The electronic republic? Evidence on the impact of the Internet on citizenship and civic engagement in the U.S. Int. J. Soc. Educ. 2006, 21, $18-43$.

64. Swan, K.O.; Hofer, M. Technology and social studies. In Handbook of Research in Social Studies Education; Sage: New York, NY, USA, 2008; pp. 307-26.

65. Lee, J.K.; Calandra, B. Can embedded annotations help high school students perform problems solving tasks using a web-based historical document? J. Res. Technol. Educ. 2004, 36, 65-84.

66. Cook-Sather, A. Authorizing students' perspectives: Toward trust, dialogue, and change in education. Educ. Res. 2002, 31, 3-14.

67. Divitini, M.; Haugalokken, O.; Morken, E.M. Blog to support learning in the field: Lessons learned from a fiasco. In Proceedings of Fifth IEEE International Conferences, Kaohsiung, Taiwan, 5-8 July 2005; pp. 219-221.

68. Mann, C.; Stewart, F. Internet Communication and Qualitative Research: A Handbook for Researching Online; Sage: London, UK, 2000.

69. Johnson, B.; Christensen, L. Educational Research: Quantitative and Qualitative Approaches; Allyn \& Bacon: Needham Heights, MA, USA, 2000.

70. Corbin, J.; Straus, A.L. Basics of Qualitative Research: Techniques and Procedures for Developing Grounded Theory; Sage: London, UK, 2008.

71. Crowe, A.R. Technology, citizenship, and the social studies classroom. Int. J. Soc. Educ. 2006, 21, 111-121.

72. Patton, M. Qualitative Research and Evaluation Methods, 3rd ed.; Sage: Thousand Oaks, CA, USA, 2002. 
73. Miles, M. B.; Huberman, A.M. Qualitative Data Analysis: A Source Book of New Methods; Sage: Beverly Hills, CA, USA, 1984.

74. Parlett, M.; Hamilton, D. Evaluation as illumination: A new approach to the study of innovatory programs. Glass, G., Ed.; In Evaluation Studies Review Annual; Sage: Beverly Hills, CA, USA, 1976.

75. LeCompte, M.D.; Preissle-Goetz, J. Qualitative research: What it is, what it isn't, and how it's done. Thompson, B.; Ed., In Advances in Social Science Methodology; Jai Press: New York, NY, USA, 1994; pp. 141-163.

76. Guba, E.G.; Lincoln, Y.S. Effective Evaluation: Improving the Usefulness of Evaluation Results Through Responsive and Naturalistic Approaches; Jossey-Bass: San Francisco, CA, USA, 1981.

77. Mauthner, N.S.; Doucet, A. Reflexive accounts and accounts of reflexivity in qualitative data analysis. Sociology 2003, 37, 413-431.

78. Merriam, S.B. Qualitative Research and Case Study Applications in Education; Jossey-Bass: San Francisco, CA, USA, 1998.

79. Horrigan, J.B. Home Broadband Adoption 2008.: Pew Charitable Trusts: Washington, DC, USA, 2008.

80. Fox, S.; Anderson, J.Q.; Rainie, L. The Future of the Internet. Pew Charitable Trusts: Washington, DC, USA, 2005.

81. Debell, M.; Chapman, C. Computer and Internet Use by Students in 2003; U.S. Department of Education, National Center for Educational Statistics: Washington DC, USA, 2003.

82. Lenhart, A.; Arafeh, S.; Smith, A.; Macgill, A.R. Writing, Technology, and Teens. Pew Charitable Trusts: Washington, DC, USA, 2008.

83. Hicks, D.; Doolittle, P.; Lee, J. Social studies teachers' use of classroom-based and Web-based historical primary sources. Theor. Res. Soc. Educ. 2004, 32, 213-247.

84. Bennett, L. Guidelines for using technology in the social studies. Soc. Stud. 2005, 96, 38-40.

85. Dewey, J. Education and Democracy; MacMillan Press: New York, NY, USA, 1916.

86. Loewen, J. Teaching What Really Happened: How to Avoid the Tyranny of Textbooks and Get Students Excited About Doing History; Teachers College Press: New York, NY, USA 2010.

87. Angell, A.V. Democratic climates in elementary classrooms: A review of theory and research. Theor. Res. Soc. Educ. 1991, 19, 241-266

88. Hess, D. Teaching students to discuss important controversial public issues. ERIC Clearing House for the Social Studies: Bloomington, IN, USA, 2001.

89. Parker, W. Education for Democracy: Contexts, Curricula, and Assessments; Information Age Publishing: Greenwich, CT, USA, 2002.

\section{Appendix A}

Student Interview Protocols

\section{1st Round of Student Interview Questions (Focus: Personal Usage of Technology)}

1. Please describe your typical day.

2. What do you do in your free time? 
3. Can you describe the technologies you use, and the how you use them?

4. What do you like best and least about technology?

5. Where do you usually access computers and the Internet?

6. Have you ever used the Internet to research or talk about political, social or economic issues? If so, give examples.

7. What do you think are the features of an engaged citizen in a global age?

\section{2nd Round of Student Interview Questions: (Focus: Global Citizenship)}

1. What sort of knowledge do you feel citizens must have in order to be good global citizens?

2. In what ways have you contributed to the betterment of your school, community, or world?

3. Describe a good global citizen you know, what makes them a good global citizen?

4. Have you used the Internet or other technologies to be an engaged global citizen? Explain.

5. How does your use of technology in the social studies compare to your use outside the social studies? What do you think about this?

\section{3rd Round of Student Interview Questions: (Focus: Social Studies, Citizenship, \& Technology)}

1. What do you think about the social studies curriculum at your school?

2. Do you have a laptop or handheld, and what do you think about using one in social studies?

3. What do you think about the school's policy that students can't bring in their computers, or access the Internet with their own computer at school?

4. What do you think about your teacher's use of technology? (Tablet PC, the Internet, PowerPoint presentations, and his website)

5. What do you think about your use of technology in the social studies?

6. How important is it to you to learn how to use these technologies in the social studies to learn about global issues and people?

\section{4th Round of Student Interview Questions: (Focus: Exit Interview)}

1. Have you ever had a negative experience with technology (i.e., texting, cyber bullying, cyber safety, slanderous and foul language)? If so, did you instigate the remarks, and how did you respond?

2. How does your technology use at home support or hurt your academic performance? What do you think about downloading copy righted materials (images, music, videos) illegally? Have you ever downloaded these materials, and if so, how frequently?

3. How do you think globalization and technology have influenced engaged citizenship?

4. What did your involvement in this study teach you?

5. What did you like and dislike about using Wikispaces?

(C) 2012 by the authors; licensee MDPI, Basel, Switzerland. This article is an open access article distributed under the terms and conditions of the Creative Commons Attribution license (http://creativecommons.org/licenses/by/3.0/). 